\title{
Isolation of endophytic bacteria from arboreal species of the Amazon and identification by sequencing of the 16S rRNA encoding gene
}

\author{
Mariza M. Coêlho ${ }^{1}$, Monica S. Ferreira-Nozawa ${ }^{2}$, Sérgio R. Nozawa ${ }^{2,3}$ and André L.W. Santos ${ }^{1}$ \\ ${ }^{1}$ Laboratório de Biotecnologia Vegetal, Universidade Nilton Lins, Manaus, AM, Brazil. \\ ${ }^{2}$ Laboratório de Expressão Gênica, Universidade Nilton Lins, Manaus, AM, Brazil. \\ ${ }^{3}$ Laboratório de Genética Química e Bioinformática, Universidade Nilton Lins, Manaus, AM, Brazil.
}

\begin{abstract}
Endophytic bacteria from three arboreal species native to the Amazon (Carapa guianenses, Ceiba pentandra, and Swietenia macrophylla), were isolated and identified, through partial sequencing of the 16S rRNA encoding gene. From these, 16 isolates were obtained, although, when compared to sequences deposited in GenBank, only seven had produced identifiable fragments. Bacillus, Pantoea and two non-culturable samples were identified. Results obtained through sequence analysis revealed low genetic diversity across the isolates, even when analyzing different species and plant structures. This is the first report concerning the isolation and identification of endophytic bacteria in these plant species.
\end{abstract}

Key words: isolation, sequencing, Bacillus, Pantoea.

Received: February 13, 2011; Accepted: July 17, 2011.

Endophytic microorganisms inhabit the inner organs and tissues of plants, such as leaves, stems, seeds and roots, during at least one period of their life-cycles, without causing diseases or producing visible external manifestation (Azevedo et al., 2000). Endophytic communities are formed mainly by fungi and bacteria. It is estimated that every plant-species constitutes a possible host for endophytic microorganisms, which, in the vast majority and despite their biotechnological potential (Ezra et al., 2004), remain unidentified. Although the interaction between these microorganisms and their respective host-plants is not, as yet, fully understood, over recent years they have been progressively more extensively employed, either in agriculture (Ryan et al., 2008), or in the production of compounds with therapeutic application, such as taxol (Stierle et al., 1993) and leucinostatin A (Strobel and Hess, 1999).

The origin, entrance pathway, colonization and transmission of endophytic bacteria have been the object of considerable research efforts (Azevedo et al., 2002). These bacteria may proliferate in seeds, the rhizosphere, the phylloplane as well as the material that results from vegetative propagation (Stierle et al., 1993; Kuske et al., 1997). Penetration into the host plant may occur via stomata, wounds, or areas of lateral root development, or may even be facilitated by the production of hydrolytic enzymes capable of

Send correspondence to André L.W. Santos. Laboratório de Biotecnologia Vegetal, UniNilton Lins, Bloco Unicenter, Av. Prof. Nilton Lins $\mathrm{n}^{\circ}$ 3259, Parque das Laranjeiras, 69058-030 Manaus, AM, Brazil. E-mail: alwsantos@yahoo.com.br. degrading the cell wall (Souza et al., 2004). Once inside, the endophytic microorganism may lodge in specific tissues, or even systemically colonize the plant, thereby establishing symbiotic, mutualistic, commensal and tropobiotic relationships (Ulrich et al., 2008).

Worldwide, the highest plant diversity is found in the Amazon biome (Strobel and Hess, 1999). Concurrently, it is not surprising that biomes characterized as extremely biodiverse are also believed to harbor significant richness and variety of microorganism populations (Figueiredo et $a l ., 2009)$. Notwithstanding, there are few reports on endophytic microorganisms isolated from Amazonian plant species. Most studies on native plants have been addressed, either to economically relevant species, as Euterpe oleracea (Strobel and Daisy, 2003), Paullinia cupana var. sorbilis (Hallmann et al., 1997), Theobroma gradiflorum (Ribeiro et al., 1999) and Bactris gasipes (Downing et al., 2000), or to anthropotoxic forms, such as Paulicourea longiflora and Strychnos cogens (Souza et al., 2004).

From a conservation view-point, the devastation observed in recent decades in the Amazon Rainforest has very likely caused the extinction of not only plant species, but also the endophytic microorganisms they host (Strobel and Daisy, 2003). Thus, more in-depth knowledge of this microbiota, as well as the interactions it maintains with host-plants and the environment, is an essential variable in the development of conservation strategies directed to sustaining environmental balance, thereby preserving biodiversity as a whole, in efforts that may pave the way for its 
biotechnological application (Azevedo et al., 2002). More specifically, such knowledge gains increased relevance in the context of Amazonian forest plant species, already undergoing intensive exploitation for timber or the production of essential oils.

In this scenario, the present work used the $16 \mathrm{~S}$ rRNA gene region for identifying endophytic bacteria in three tree-species, native to the Amazon rainforest: Carapa guianenses Aublet (andiroba), Ceiba pentandra (L.) Gaertn (kapok tree, locally known as sumauma) and Swietenia macrophylla King (big-leaf mahogany). The plant species chosen have already been intensively exploited by the timber industry and manufacturers of aromatherapy products, thereby causing a significant decrease in populations in those areas where they are native.

Plant material (leaves, apices, stems and seeds) was collected from five seedlings each of Carapa guianenses Aublet (andiroba), Ceiba pentandra (L.) Gaertn (sumaúma), and Swietenia macrophylla King (big-leaf mahogany), originally from the forest nursery of UniNilton Lins, Manaus, AM, Brazil. The material was first disinfected by treatment with $70 \%(\mathrm{v} / \mathrm{v})$ ethanol for $5 \mathrm{~min}$, followed by sodium hypochlorite ( $\mathrm{NaClO}) 10 \%(\mathrm{v} / \mathrm{v})$ for $10 \mathrm{~min}$ and then rinsed three times with distilled autoclaved water. To confirm disinfection success, $300-\mu \mathrm{L}$ aliquots were taken from the final autoclaved water wash-offs, and transferred onto a $2 x Y T$ culture medium ( $16 \mathrm{~g} / \mathrm{L}$ tryptone, $10 \mathrm{~g} / \mathrm{L}$ yeast extract, $5 \mathrm{~g} / \mathrm{L} \mathrm{NaCl}$ ) in Petri dishes, and incubated for 7 days at $37 \pm 2{ }^{\circ} \mathrm{C}$.

After asepsis, $8 \times 8 \mathrm{~mm}$ leaf fragments, seeds, apices and $50 \mathrm{~mm}$ stem sections were inoculated in Petri dishes containing 2 xYT medium supplemented with $0.3 \mathrm{~g} / \mathrm{L}$ Benlate ${ }^{\circledR}$ (DuPont), to inhibit growth of fungal colonies. The material was then incubated for 7 days at $37 \pm 2{ }^{\circ} \mathrm{C}$. Plant material presenting bacteria colonies was transferred to liquid culture medium ( $2 \times Y T)$, and cultivated for $14 \mathrm{~h}$ in the dark at $37 \pm 2{ }^{\circ} \mathrm{C}$, with $220 \mathrm{rpm}$ orbital shaking. After three days, $1.5 \mathrm{~mL}$ aliquots were separated from the cultures and centrifuged at $12,000 \times \mathrm{g}$, for $15 \mathrm{~min}$ at $4{ }^{\circ} \mathrm{C}$. The supernatant was disposed of and the pellet stored in glycerol $70 \%$ $(\mathrm{v} / \mathrm{v})$ at $-80^{\circ} \mathrm{C}$, awaiting DNA extraction.

DNA extraction was in accordance with the protocol described in the Wizzard Genomic DNA Purification kit (Promega Co.). Extracted DNA was electrophoresed in 1\% $(w \mid v)$ agarosegels, stained with ethidium bromide, and quantitatively analyzed in a micro-volume spectrometer (NanoDrop 1000, V3.6.0, Thermo Scientific, Waltham, MA, USA). PCR was amplifications were carried out using specific primers for the $16 \mathrm{~S}$ rRNA encoding gene in a $25-\mu \mathrm{L}$ final volume containing $200 \mathrm{ng} / \mu \mathrm{L}$ of bacterial DNA, $12.5 \mu \mathrm{L}$ of Green Master Mix (Promega Co.), $8.5 \mu \mathrm{L}$ of sterile milli-Q water, and $1 \mu \mathrm{L}$ of each primer. The primers were the same as those used by Kuske et al. (1997): primer $8 \mathrm{~F}$ (forward, 5'-AGA GTT TGA TCC TGG CTC
AG-3'), and primer 1100R (reverse, 5'-GGG TTG CGC TCG TTG-3'). DNA was amplified in a thermal cycler (Techne TC-412, Barloworld Scientific Ltd, UK), according to a 35 -cycle program: $30 \mathrm{~s}$ at $92{ }^{\circ} \mathrm{C} ; 45 \mathrm{~s}$ at $44{ }^{\circ} \mathrm{C} ; 1 \mathrm{~min}$ at $72{ }^{\circ} \mathrm{C}$; and a final $5 \mathrm{~min}$ extension cycle at $72{ }^{\circ} \mathrm{C}$. PCR products were cloned in a $p G E M-T$ easy vector system (Promega,), in accordance with manufacturer's instructions. Plasmid DNA of selected clones was isolated, according to the miniprep procedure.

Sequencing reactions were carried out in microplates using the kit DNA Sequencing-Big Dye Terminator Cycle Sequencing Ready ABI Prism version 3. Sequencing reactions were conducted in a $10-\mu \mathrm{L}$ final volume of a solution prepared with $1 \mu \mathrm{L}$ Big Dye, $1 \mu \mathrm{L}$ primer, $3 \mu \mathrm{L}$ plasmid DNA, $1.5 \mu \mathrm{L}$ buffer, and $3.5 \mu \mathrm{L}$ sterile milli-Q water. The primer used was M13/pUC 1211 (forward; 5'-GTA AAA CGA CGG CCA GT-3'). The quality of the sequences was assessed based on electropherograms generated with $\mathrm{Se}$ quencing Analysis 3.5 software, and analyzed with Phred/Phrap/Consed software (Guimarães VC, 1998, MSc Dissertação Universidade Federal de São Carlos/ Universidade Federal do Amazonas). Appropriate sequences were selected using Blast2go for automated annotation. Initially, sequences were analyzed for nucleotide similarity in comparison with sequences deposited in GenBank, and then accessed via the National Center for Biotechnology Information (NCBI) website using the BlastN tool (Altschul et al., 1997).

Molecular phylogenetic analysis by Maximum Parsimony (MP) was done using the Close-Neighbor-Interchange Algorithm (Tamura and Nei, 1993) with search level 0 . Initial trees were obtained through the random addition of sequences (10 replicates). Analysis involved all the nucleotide sequences. Included codon positions were $1 \mathrm{st}+2 \mathrm{nd}+3 \mathrm{rd}+$ Noncoding. All positions containing gaps and missing data were eliminated.

For estimating the Maximum Likelihood (ML) values, a user-specified toplogy was used. The evolutionary history was inferred by using the Maximum Likelihood method based on the Tamura-Nei model (Tamura and Nei, 1993). Initial tree(s) for the heuristic search were obtained automatically as follows. When the number of common sites was $<$ 100 or less than one fourth of the total number of sites, the maximum parsimony method was used; otherwise, the BIONJ method with MCL distance matrix was used. Evolutionary analysis was with MEGA5 (Tamura et al., 2011).

As a rule, plants may be simultaneously colonized by a large variety of endophytic bacteria. This bacterial diversity is affected by a number of factors, such as specificity and age of the host-plant, season of the year, ecological niche, and type of tissue (Azevedo et al., 2002). The present work analyzed the diversity of endophytic bacteria isolated from various plant tissues, as caulinar apices, foliar discs, stems and mature seeds, from three arboreal species, native to the Amazon Rainforest, namely, Carapa guianenses (andiroba), 
Ceiba pentandra (sumauma) and Swietenia macrophylla (mahogany). The isolation and growth of bacteria in the culture medium used (2xYT), and the subsequent analysis of partial sequencing in nucleotides of the $16 \mathrm{~S}$ rRNA encoding gene, lead to the identification of 16 bacterial strains. As to the plant structures used, $18,75 \%$ of the isolates were obtained from the apices and stems of C. guianiensis, 25\% from the seeds and apices of C. pentandra, and $56.25 \%$ from the stems and leaves of S. macrophylla.

The isolation of endophytic bacteria in a culturemedium is considered one of the simplest methods, when assessing bacterial communities (Andreote et al., 2009). However, in terms of diversity, and when considering the total population, this can lead to underestimation, since identification is restricted to those actually capable of growing in the specific culture-medium chosen. Furthermore, differences in growth-rate during in vitro incubation, i.e., fast or slow, or, recalcitrance to the cell-lysis process, as observed in Actinobacteria, may also affect the number of isolates obtained (Glare and O'Callaghan, 2000). Most studies based on isolation in a culture medium are faced with such limitations, although the results obtained do indeed shed more light on the way such bacterial populations are structured (Andreote et al., 2009).

In the present work, results were obtained for only seven samples, in which fragments with approximately $1,200 \mathrm{bp}$ were observed (Figure S1). The identification of endophytic bacteria based on the comparison between the sequences obtained and those deposited in GenBank using the BlastN revealed the prevalence of Bacillus. Of the total number of samples analyzed, $57.14 \%$ belonged to the genus Bacillus and $14.28 \%$ to Pantoea, whereas $28.57 \%$ were non-culturable bacteria. A phylogenetic analysis of isolates is shown in Supplementary Figure S2. Gram positive and Gram negative endophytic bacteria have already been isolated from many tissue types in numerous plant-species (Glare and O'Callaghan, 2000). Recently, the endophytic microbiota of several plant-species have been studied, the most prevalent genera isolated including Pseudomonas, Erwinia, Bacillus, Burkholderia, Xanthomonas and Enterobacter (Kuske et al., 1997). Bacteria belonging to the genus Pantoea have likewise been observed in citrus-plant species, as well as clover and sugarcane (Araújo et al., 2002; Polanczyk and Alves, 2003).

On identifying isolates at the species level, incongruities were observed. When sequences obtained in the present analysis were compared to those deposited in GenBank using the BlastN, it was observed that one same given sequence was actually similar to those sequences of more than one species (Table 1). The genetically related species were Bacillus thuringiensis, B. cereus, B. subtilis, B. amyloliquefaciens, B. polyfermenticus, B. anthracis, B. velezensis and Pantoea dispersa. According to Polanczyk and Alves (2003), though the term Bacillus thuringiensis is used for one single species (based on taxonomic traits), the bacterium belongs to a complex formed by several species

Table 1 - Identification of endophytic bacteria based on the 16S rRNA region sequence compared to sequences deposited in GenBank, using Blastn.

\begin{tabular}{|c|c|c|c|c|c|c|}
\hline Isolate & Identity $^{1}$ & Plant species & Plant tissue & Max Score & Max ident & $\begin{array}{c}\text { Accession number } \\
\text { (GenBank) }\end{array}$ \\
\hline $1 b$ & Pantoea dispersa & Carapa guianensis & Apex & 684 & $99 \%$ & FJ756350.1 \\
\hline $5 c$ & Uncultured bacterium & Carapa guianensis & Leaf & 652 & $99 \%$ & AY838532.1 \\
\hline $6 \mathrm{~b}$ & Bacillus anthracis & Ceiba pentandra & Seed & $1.452 \mathrm{e}+04$ & $96 \%$ & СР001598.1 \\
\hline $6 \mathrm{c}$ & Bacillus cereus & Ceiba pentandra & Seed & $1.784 \mathrm{e}+04$ & $95 \%$ & СР001186.1 \\
\hline $6 \mathrm{~d}$ & Bacillus cereus & Ceiba pentandra & Seed & 1635 & $97 \%$ & FJ841975.1 \\
\hline $6 e$ & $\begin{array}{l}\text { Bacillus thuringiensis } \\
\text { serovar konkukian }\end{array}$ & Ceiba pentandra & Seed & $2.007 \mathrm{e}+04$ & $96 \%$ & AE017355.1 \\
\hline $6 f$ & Bacillus cereus & Ceiba pentandra & Seed & $1.856 \mathrm{e}+04$ & $96 \%$ & СР001186.1 \\
\hline $6 \mathrm{~g}$ & Bacillus sp. & Ceiba pentandra & Seed & 1443 & $96 \%$ & AB126763.1 \\
\hline $6 \mathrm{~h}$ & Bacillus cereus & Ceiba pentandra & Seed & $1.477 \mathrm{e}+04$ & $100 \%$ & CP001186.1 \\
\hline $6 \mathrm{i}$ & Bacillus cereus & Ceiba pentandra & Seed & $2.114 \mathrm{e}+04$ & $98 \%$ & СР001407.1 \\
\hline $9 \mathrm{a}$ & Bacillus anthracis & Swietenia macrophylla & Stem & $1.315 \mathrm{e}+04$ & $94 \%$ & СР001598.1 \\
\hline $9 b$ & Bacillus sp. & Swietenia macrophylla & Stem & 1472 & $98 \%$ & EF428972.1 \\
\hline $9 \mathrm{~d}$ & Bacillus thuringiensis & Swietenia macrophylla & Stem & 1249 & $98 \%$ & AM778997.1 \\
\hline $9 \mathrm{e}$ & Bacillus cereus & Swietenia macrophylla & Stem & $1.907 \mathrm{e}+04$ & $98 \%$ & CP001186.1 \\
\hline $9 f$ & Bacillus cereus & Swietenia macrophylla & Stem & $2.036 \mathrm{e}+04$ & $98 \%$ & СР001407.1 \\
\hline $9 \mathrm{~g}$ & Bacillus cereus & Swietenia macrophylla & Stem & 1530 & $99 \%$ & AB508868.1 \\
\hline $9 \mathrm{~h}$ & Bacillus anthracis & Swietenia macrophylla & Stem & $1.639 \mathrm{e}+04$ & $99 \%$ & СР001598.1 \\
\hline $9 \mathrm{i}$ & Bacillus cereus & Swietenia macrophylla & Stem & 1454 & $97 \%$ & AY224383.1 \\
\hline
\end{tabular}


Table 1 (cont.)

\begin{tabular}{|c|c|c|c|c|c|c|}
\hline Isolate & Identity $^{1}$ & Plant species & Plant tissue & Max Score & Max ident & $\begin{array}{c}\text { Accession number } \\
\text { (GenBank) }\end{array}$ \\
\hline $9 \mathrm{j}$ & Bacillus thuringiensis & Swietenia macrophylla & Stem & 1341 & $99 \%$ & FJ932761.1 \\
\hline $13 \mathrm{a}$ & Uncultured Bacillus sp. & Swietenia macrophylla & Leaf & 1158 & $98 \%$ & EU371583.1 \\
\hline $13 b$ & Bacillus subtilis & Swietenia macrophylla & Leaf & 970 & $100 \%$ & GQ161967.1 \\
\hline $13 \mathrm{c}$ & Bacillus sp. & Swietenia macrophylla & Leaf & 515 & $99 \%$ & FJ465166.2 \\
\hline $13 \mathrm{c}$ & Bacillus subtilis & Swietenia macrophylla & Leaf & 1476 & $98 \%$ & EU257444.1 \\
\hline $13 d$ & Bacillus amyloliquefaciens & Swietenia macrophylla & Leaf & $1.352 \mathrm{e}+04$ & $99 \%$ & СР000560.1 \\
\hline $13 \mathrm{e}$ & Bacillus velezensis & Swietenia macrophylla & Leaf & 1437 & $98 \%$ & EU852930.1 \\
\hline $13 \mathrm{f}$ & Bacillus velezensis & Swietenia macrophylla & Leaf & 1483 & $99 \%$ & EU852930.1 \\
\hline $13 \mathrm{~g}$ & Bacillus amyloliquefaciens & Swietenia macrophylla & Leaf & 1294 & $97 \%$ & FJ685773.1 \\
\hline $13 \mathrm{~h}$ & Bacillus amyloliquefaciens & Swietenia macrophylla & Leaf & 1391 & $99 \%$ & FJ960508.1 \\
\hline $13 \mathrm{j}$ & Bacillus subtilis & Swietenia macrophylla & Leaf & 1393 & $97 \%$ & EU862566.1 \\
\hline $14 \mathrm{a}$ & Bacillus amyloliquefaciens & Swietenia macrophylla & Leaf & $1.342 \mathrm{e}+04$ & $98 \%$ & СР000560.1 \\
\hline $14 b$ & Bacillus polyfermenticus & Swietenia macrophylla & Leaf & 1489 & $98 \%$ & AY149473.2 \\
\hline $14 \mathrm{c}$ & Bacillus sp. & Swietenia macrophylla & Leaf & 453 & $97 \%$ & FJ654441.1 \\
\hline $14 d$ & Bacillus subtilis & Swietenia macrophylla & Leaf & 1184 & $98 \%$ & EF428247.2 \\
\hline $14 \mathrm{e}$ & Bacillus sp. & Swietenia macrophylla & Leaf & 749 & $99 \%$ & FJ463041.1 \\
\hline $14 f$ & Bacillus polyfermenticus & Swietenia macrophylla & Leaf & 1520 & $99 \%$ & AY149473.2 \\
\hline $14 \mathrm{~h}$ & Bacillus polyfermenticus & Swietenia macrophylla & Leaf & 1404 & $98 \%$ & AY149473.2 \\
\hline $14 \mathrm{~g}$ & Bacillus sp. & Swietenia macrophylla & Leaf & 1227 & $98 \%$ & FJ465166.2 \\
\hline $14 \mathrm{i}$ & Bacillus polyfermenticus & Swietenia macrophylla & Leaf & 1415 & $98 \%$ & AY149473.2 \\
\hline $16 \mathrm{a}$ & Uncultured bacterium & Ceiba pentandra & Apex & 619 & $99 \%$ & GQ096960.1 \\
\hline
\end{tabular}

${ }^{1}$ Seven isolates were used for analysis, four for Bacillus, one for Pantoea and two for uncultured bacteria.

(B. anthracis, B. cereus, B. mycoides, B. thuringiensis, and $B$. weihenstephanensis). This complex is called $B$. cereus. Molecular methods, the analysis of fatty acids and phospholipids, comparison of the 16S rRNA sequence, among other analytical approaches, have shown that $B$. thuringiensis and B. cereus are, in fact, one and the same species. Therefore, the need for a better distinction between the two has become the central topic of several taxonomy studies (Gordon et al., 1998).

The results obtained on analyzing partial sequences of the 16S rRNA region encoding gene, demonstrate the low genetic divergence between endophytic bacteria isolated from the three arboreal plant-species native to the Amazon. This may be linked to the growth conditions adopted, as well as to the low specificity of the primers used. Notwithstanding, the plant species used in the present study showed good promise as a source of sampling material in studies about the isolation and identification of bacterial genera that may have potential biotechnological applications.

\section{Acknowledgments}

The authors are indebted to the Post-Graduation Program Stricto Sensu, Academic MSc course in Urban Biology, UniNilton Lins.

\section{References}

Altschul SF, Gish W, Miller W, Myers EW and Lipman DJ (1997) Gapped BLAST and PSI-BLAST: A new generation of protein database search programs. Nucleic Acids Res 25:3389-3402.

Andreote FD, Araújo WL, Azevedo JL, Van Elsas JD, Rocha UN and Van Overbeek LS (2009) Endophytic colonization of potato (Solanum tuberosum L) by a novel competent bacterial endophyte, Pseudomonas putida strain P9, and its effect on associated bacterial communities. Appl Environ Microbiol 75:3396-3406.

Araújo WL, Marcon J, Maccheroni Júnior W, Van Elsas JD, Van Vuurde JWL and Azevedo JL (2002) Diversity of endophytic bacterial populations and their interaction with Xylella fastidiosa in citrus plant. Appl Environ Microbiol 68:4906-4914.

Azevedo JL, Maccheroni Jr W, Pereira JO and Araújo WL (2000) Endophytic microorganisms: A review on insect control and recent advances on tropical plants. Electron J Biotechnol $3: \mathrm{e} 1-4$.

Azevedo JL, Maccheroni Júnior W, Araújo WL and Pereira JO (2002) Microrganismos endofíticos e seu papel em plantas tropicais. In: Serafini LA, Barros NM and Azevedo JL (eds) Biotecnologia: Avanços na Agricultura e na Agroindústria. EDUCS, Caxias do Sul, pp 235-268. 
Downing KJ, Leslie G and Thompson JA (2000) Biocontrol of the sugar-cane borer Eldana saccharina by expression of the Bacillus thuringiensis crylAc7 and Serratia marcescens chiA gene in sugar-cane associated bacteria. Appl Environ Microbiol 66:2804-2810.

Ezra D, Castillo UF, Strobel GA, Hess WM, Porter H, Jensen JB, Contron MAM, Teplow DB, Sears J, Maranta M, et al. (2004) Coronamycins, peptide antibiotics produced by a verticullate Streptomyces sp (MSU-2110) endophytic on Monstera sp. Microbiology 150:785-793.

Figueiredo JEF, Gomes EA, Guimarães CT, Lana UGP, Teixeira MA, Lima GVC and Bressan W (2009) Molecular analysis of endophytic bacteria from the genus Bacillus isolated from tropical maize (Zea mays L). Braz J Microbiol 40:522-534.

Glare TR and O'Callaghan M (2000) Bacillus thuringiensis: Biology, Ecology and Safety. John Wiley \& Sons, Chichester, $350 \mathrm{pp}$.

Gordon D, Abajian C and Green P (1998) Consed: A graphical tool for sequence finishing. Genome Res 8:195-202.

Hallmann J, Quadt-Hallmann A, Mahaffee WF and Klopper JW (1997) Bacterial endophytes in agricultural crops. Can J Microbiol 43:895-914.

Kuske CR, Barns SM and Busch JD (1997) Diverse uncultivated bacterial groups from soils of the arid Southwestern United States that are present in many geographic regions. Appl Environ Microbiol 63:3614-3621.

Polanczyk R and Alves S (2003) Bacillus thuringiensis: Uma breve revisão Agrociencia 7:1-10.

Ribeiro JELS, Hopkins MJG, Vicentini A, Sothers CA, Costa MAS, Brito JM, Souza MAD, Martins LHP, Lohmann LG, Assunção PACL, et al. (1999) Flora da Reserva Ducke: Guia de Identificação das Plantas Vasculares de uma Floresta de Terra-Firme na Amazônia Central. INPA, Manaus, $816 \mathrm{pp}$.

Ryan RP, Germaine K, Franks A, Ryan DJ and Dowling DN (2008) Bacterial endophytes: Recent developments and applications. FEMS Microbiol Lett 278:1-9.

Souza AQL, Souza ADL, Astolfi Filho S, Belém Pinheiro ML, Sarquis MIM and Pereira JO (2004) Atividade antimicro- biana de fungos endofíticos isolados de plantas tóxicas da Amazônia: Palicourea longiflora (aubl) rich and Strychnos cogens bentham. Acta Amazonica 34:185-195.

Stierle A, Strobel G and Stierle D (1993) Taxol and taxane production by Taxomyces andreanae, an endophytic fungus of Pacific Yew. Science 260:214-216.

Strobel G and Hess WM (1999) Glucosylation of the peptide leucinostatina A, produced by an endophytic fungus of European yew, may protect the host from leucinostatin toxicity. Chem Biol 4:529-536.

Strobel G and Daisy B (2003) Bioprospecting for microbial endophytes and their natural products. Microbiol Mol Biol Rev 67:491-502

Tamura K and Nei M (1993) Estimation of the number of nucleotide substitutions in the control region of mitochondrial DNA in humans and chimpanzees. Mol Biol Evol 10:512526.

Tamura K, Peterson D, Peterson N, Stecher G, Nei M and Kumar S (2011) MEGA5: Molecular Evolutionary Genetics Analysis using maximum likelihood, evolutionary distance, and maximum parsimony methods. Mol Biol Evol doi: $10.1093 / \mathrm{molbev} / \mathrm{msr} 121$.

Ulrich K, Ulrich A and Ewald D (2008) Diversity of endophytic bacterial communities in poplar grown under field conditions. FEMS Microbiol Ecol 63:169-180.

\section{Supplementary Material}

The following online material is available for this article:

Figure S1 - Agarose gel showing the PCR products

Figure S2 - Molecular phylogenetic analysis

This material is available as part of the online article at http:www.scielo.br/gmb.

Associate Editor: Luís Carlos de Souza Ferreira

License information: This is an open-access article distributed under the terms of the Creative Commons Attribution License, which permits unrestricted use, distribution, and reproduction in any medium, provided the original work is properly cited. 
13 Figure S1 - Agarose gel 1\% (w/v) showing the PCR products of the amplification of the 14 16S rRNA encoding region. 1: 200-bp ladder; 2-7: isolates. 


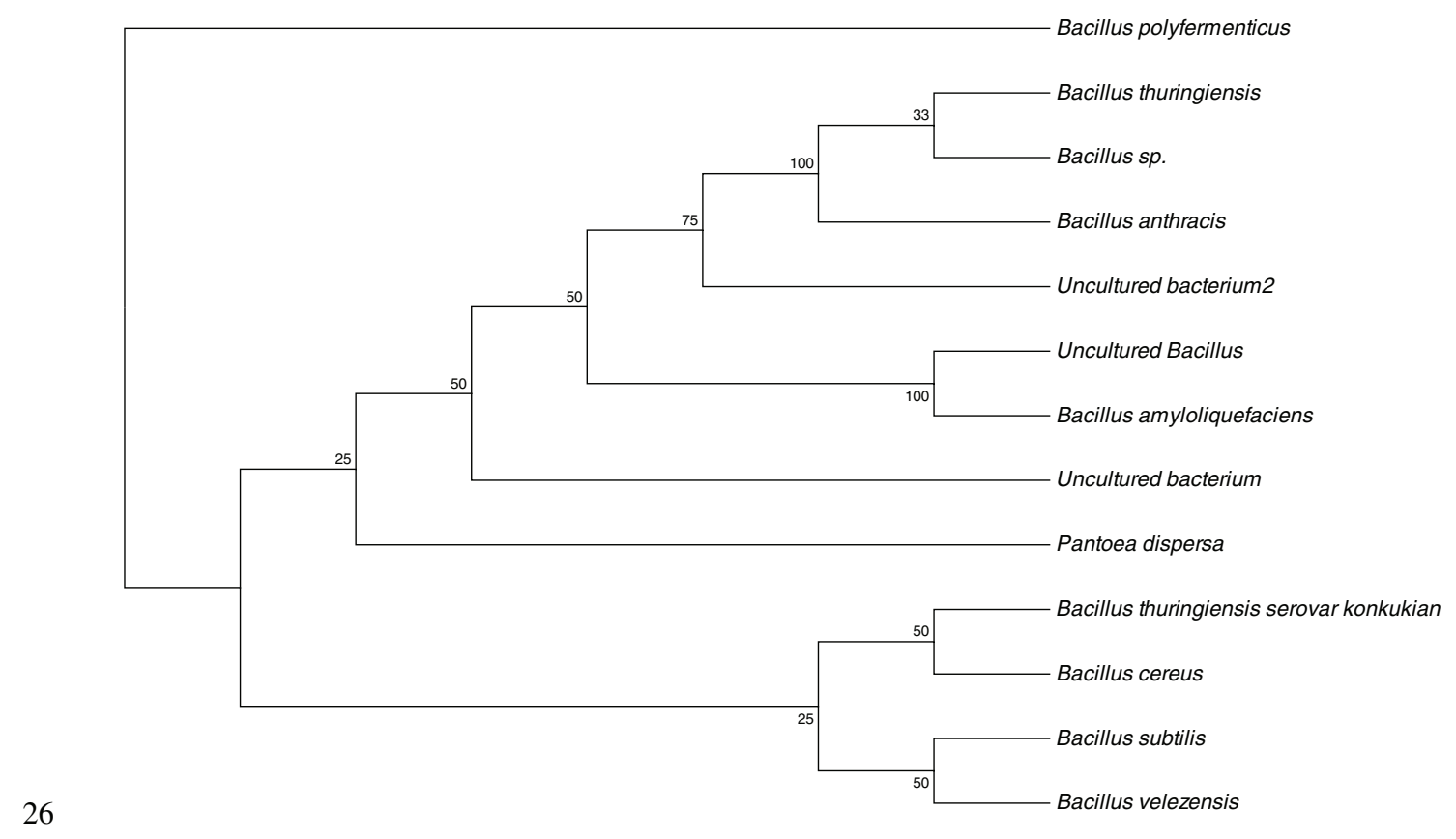

$27 \quad(a)$

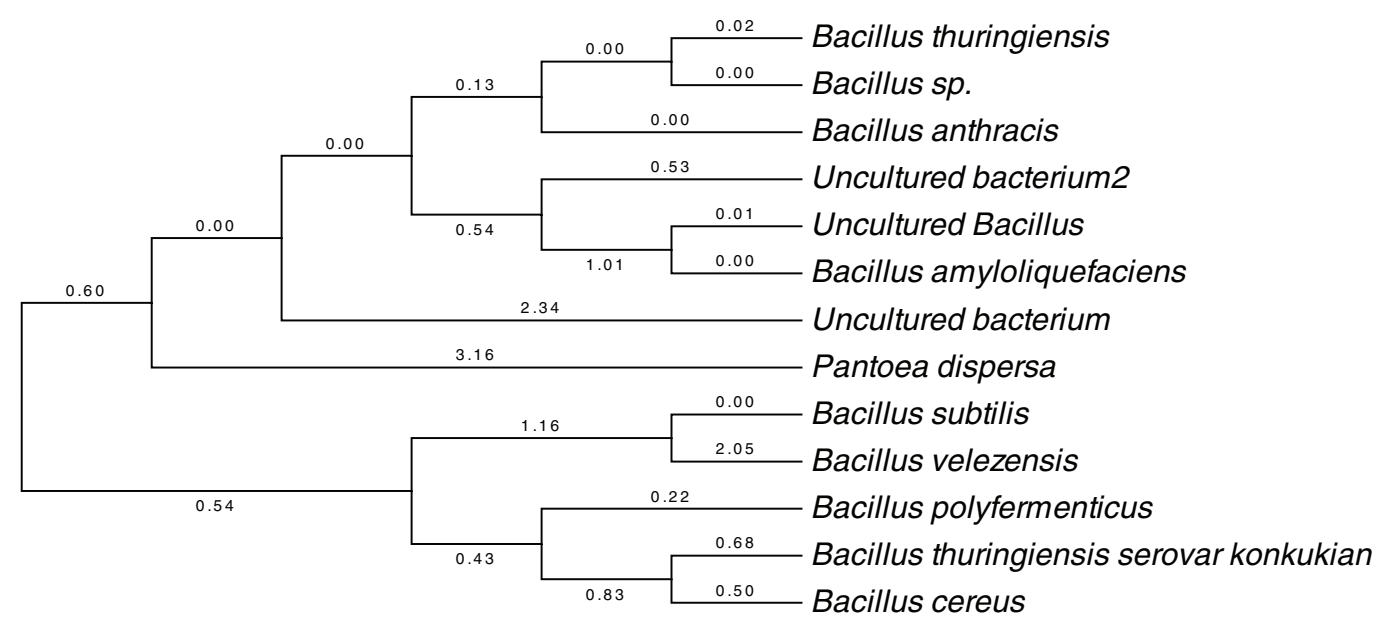

(b)

Figure S2 - Phylogenetic analysis showing the relationship of the 16S rRNA gene sequences of isolates. The trees were generated using (a) Molecular Phylogenetic anaylsis by Maximum Parsimony (MP) analysis of taxa and (b) Maximum Likelihood (ML) method. 